\title{
Acts of Genocide and International Law
}

Actos de genocidio y derecho internacional

Autores: Stefan Kirchner, Doly P. Orozco Lopez DOl: https://doi.org/10.25058/1794600X.1906 


\title{
ACTS OF GENOCIDE AND INTERNATIONAL LAW*
}

\author{
Actos de genocidio y derecho internacional
}

Atos de genocídio e direito internacional

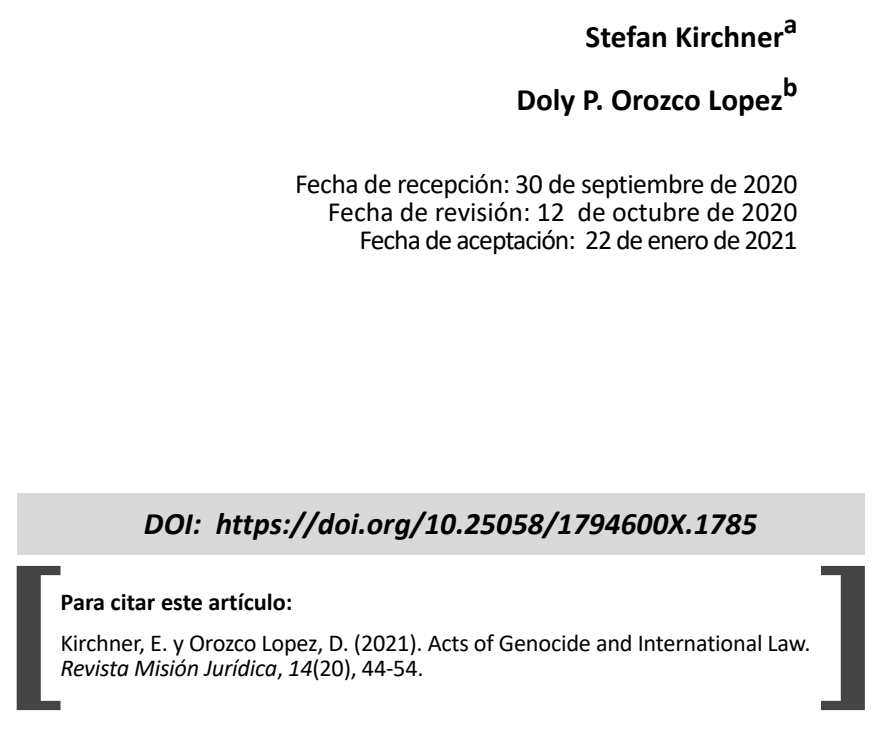

\section{ABSTRACT}

In addition to the loss of over 200,000 lives due to the COVID-19 pandemic, racist violence, riots, wildfires, storms and political controversies in an election year, the United States of America might now also see acts of genocide. If recent reports are confirmed, multiple acts of genocide have been committed against migrants from Central America, targeting in particular women and children. This text outlines the elements which define the crime of genocide under international law and explains the special, jus cogens, status the prohibition of genocide has under both international treaty law and

\footnotetext{
* Artículo de reflexion.

a. Research Professor of Arctic Law, University of Lapland, Rovaniemi, Finland. Adjunct Professor (dosentti) of Fundamental and Human Rights, University of Lapland, Rovaniemi, Finland. Senior Researcher, Research Cluster "Impact of Globalization on Law", Vytautas Magnus University, Kaunas, Lithuania.

b. Master in Public Policy, Autonomous Metropolitan University, México City, México. Political Scientist, Universidad del Cauca, Popayán, Colombia
} 
customary international law. It includes a call for further investigations, pursuant to the obligation of all States to combat genocid.

\section{KEY WORDS}

Genocide; United States of America; human rights; migration; Latin America.

\section{RESUMEN}

Además de la pérdida de más de 200.000 vidas debido a la pandemia por el COVID-19, violencia racista, protestas, incendios forestales, tormentas y controversias políticas en un año de elecciones, Estados Unidos de América podría ahora ver también actos de genocidio. Si se confirman informes recientes, múltiples actos de genocidio contra migrantes de América Central han sido cometidos, atacando especialmente a mujeres y niños. Este texto presenta los elementos que definen el crimen de genocidio bajo el derecho internacional y explica el especial estatus de ius cogens que la prohibición del genocidio tiene tanto bajo los tratados de derecho internacional como del derecho internacional consuetudinario. Asimismo, este texto incluye un llamado a realizar más investigaciones de acuerdo con la obligación de todos los Estados de combatir el genocidio.

\section{PALABRAS CLAVE}

Genocidio, Estados Unidos de América, derechos humanos, migración, América Latina..

\section{RESUMO}

Além da perda de mais de 200.000 vidas devido à pandemia COVID-19, violência racista, protestos, incêndios florestais, tempestades e controvérsias políticas em um ano eleitoral, os Estados Unidos da América agora também podem testemunhar atos de genocídio. Se os relatórios recentes forem confirmados, vários atos de genocídio contra migrantes da América Central foram cometidos, especialmente contra mulheres e crianças. Este texto apresenta os elementos que definem o crime de genocídio sob o direito internacional e explica o status especial de jus cogens que a proibição do genocídio tem sob os tratados de direito internacional e o direito internacional consuetudinário. Da mesma forma, este texto inclui um apelo à realização de mais investigações em conformidade com a obrigação de todos os Estados de combater o genocídio.

\section{PALAVRAS CHAVE}

Genocidio; Estados Unidos da América; direitos humanos; migração; América Latina.

\section{INTRODUCTION}

The word "genocide" evokes ideas and brings specific images to one's mind.In particular the situations in Rwanda and Bosnia in the 1990s still inform the public imagination of the term genocide. But acts of genocide also happen today and in places which are even less accessible to the media than Rwanda and Bosnia were in the 1990s. This lack of information makes it difficult for outsiders to dermine whether acts of violence and oppression actually amount to genocide in the legal sense of the term, a problem which emphasizes the role of impartial investigations and of a free press in the persecution of perpetrators of genocide and in the prevention of future acts of genocide. Such acts of violence which might meet the legal definition of genocide might occur in the Amazon rain forest or detention centers in China or the United States. It is against this backdrop of the possibility that acts of genocide are being committed in the Americas at this moment that this article aims to answer the question which measures can actually amount to acts of genocide under international law. In light of the current allegations of forced sterilizations committed against migrant women from Latin American who are detained in the United States of America, particular attention will also be given to the domestic legal situation in the United States, which reflects the current international legal norms. It is the objective of this text to highlight the prevalence of activities which amount to acts of genocide as defined under international law and to place them in the historic context of, especially, Latin America.

Part 2 of this article provides the reader with an overview over the current situation in the United States, in particular concerning the treatment of migrants from Latin America, especially of Latin American migrant women and children. Special attention will be given to the transfer of children between ethnic groups and forced sterilizations. In part 3, a definition of genocide will be provided, setting the stage for part 4 , which introduces the reader to criminal law responses to genocide, including the duty to investigate. Part 5 places these 
observations into the wider Latin American context, in particular the history of Latin America and the current situation.

\section{ACT'S OF GENOCIDE 2.1 Trump's America}

As the 3rd of November, the date of the next U.S. presidential election, approaches, the attention of the world will be drawn not only to Washington D.C. but also to the many challenges the American people face today, from the pandemic which has killed almost 200,000 Americans in around half a year, racial injustice, racist violence, climate change and environmental pollution to disasters, such as the storms currently underway in the Gulf of Mexico and the wildfires which threaten the homes of many Americans and which cover large parts of the country under a blanket of smoke. Behind the smoke of wildfires and tear gars and the glare of spotlights, far removed from TV cameras, men, women and children are made to suffer for daring to share the American dream.

The authors are expert on international law and political sciences, respectively, and do not use the word genocide lightly. Today, we are forced to use it, because U.S. authorities might be guilty of this heinous crime. Recent allegations are so serious that they need to be investigated not only as a matter of public and criminal, but also as a matter of international law.

\subsection{Transfer of Children between Ethnic Groups}

Due to the anti-immigration policies of the current American government, refugees and would-be immigrants, including children, from Latin American countries are held in detention centres run by the American government. Despite significant international concerns, U.S. authorities continue to hold children in cages, separated from their parents (Long, 2019). It has also been reported that American families have adopted children of parents who have been deported from the United States back to Central America (Associated Press, 2018). Especially readers from Argentina and Spain will be reminded of some of the darkest episodes in these nations' histories, when children of dissidents were taken from them and adopted by regime loyalists during Argentina's Dirty War (Goldman, 2012) and Franco's dictatorship in Spain (López-Terra, 2018). From the beginning of the current U.S. government's policy in 2018 until spring 2020,2,500 children are thought to have been taken from their parents (Guardian staff and agencies, 2020).

\subsection{Forced sterilizations}

It has now been reported that Latin American women who are detained by U.S. immigration authorities have been forced to undergo hysterectomies, i.e., the removal of the uterus, without their consent and without a medical reason for such a procedure (Lambe, 2020). U.S. authorities deny these charges (BBC, 2020) while calls for investigations are growing louder (BBC, 2020).

Forced sterilizations and other attempts to prevent births in ethnic groups are not a new concept. Earlier this year, it was reported by the Associated Press that China is using large-scale sterilization campaigns, coupled with the threat of detention (Associated Press, 2020) in the camps which have been erected there in recent years and which have been compared as concentration camps (Washington Post Editorial Board, 2020), although their official purpose is "re-education" (BBC, 2019), a term used in totalitarian societies to describe efforts to quell dissent. The purpose of these camps, regardless of the labelused to describe them, is to render Uighur identity in China moot (BBC, 2019). The Chinese government's efforts to make Uighur identity in China disappear mirrors the experience of many indigenous peoples in the past, peoples which were forcibly assimilated. On the individual level, Latin American children are robbed of their identity when they are forcibly separated from their parents and adopted by U.S. families. Forced hysterectomies take the same idea one step further. These violations of the physical integrity and dignity of women aim at preventing Latin Americans, who tried to escape poverty and violence in their home countries and to build a future for their families in the United States, from 
having children in the first place. If the allegations concerning women detained by U.S. authorities are confirmed, such action, like the forced transfer of Latin American children to white American families, would raise the question whether the persons acting on behalf of U.S. authorities are committing genocide.

\section{DEFINITION OF GENOCIDE}

Such a serious situation requires a detailed investigation. All facts have to be made public and if crimes have been committed, those responsible have to be brought to justice. This is especially the case as genocide is among the most serious crimes imaginable, both under international and national law.

Article II of the Genocide Convention (Genocide Convention, 1951), which has been ratified by the United States of America and which therefore is part of the law of the land in the U.S., shows the severity of such forced sterilizations among immigrant women from Latin America who are detained by the U.S. government. The norm reads as follows:

"In the present Convention, genocide means any of the following acts committed with intent to destroy, in whole or in part, a national, ethnical, racial or religious group, as such:

(a) Killing members of the group;

(b) Causing serious bodily or mental harm to members of the group;

(c) Deliberately inflicting on the group conditions of life calculated to bring about its physical destruction in whole or in part;

(d) Imposing measures intended to prevent births within the group;

(e) Forcibly transferring children of the group to another group." (Genocide Convention, Article II)

The timeless importance of Article II of the Genocide Convention is reflected by the fact that the text of Article 6 of the Rome Statute of the International Criminal Court (Rome Statute of the International Criminal Court, 1998) mirrors that of Article II of the Genocide Convention.

The definition of genocide under international law and national legislation includes, inter alia, the forced transfer of children, that is, people under the age of 18 (Cryer, 2018:746) and measures which are meant to prevent children from being born in a specific group, a rule which is a reaction to the crimes committed in Nazi Germany (Cryer, 2018: 746).

\section{CRIMINAL LAW}

\subsection{International Criminal Law}

The transfer of Latin American children from their parents has been reported in the past. If the reports of forced sterilizations would be confirmed, this would be another indicator that not only in China but also in America acts of genocide are being committed in the year 2020 .

It would also be an indicator that these events are not singular in nature but part of a plan. This is an indicator that these actions were taken with the "intent to destroy, in whole or in part, a national, ethnical, racial or religious group" (Genocide Convention, 1951: Article II), which is the level of intent required under Article II of the Genocide Convention. In fact, international criminal liability does neither begin nor end there. Article III of the Genocide Convention reads as follows:

"The following acts shall be punishable:

(a) Genocide;

(b) Conspiracy to commit genocide;

(c) Direct and public incitement to commit genocide;

(d) Attempt to commit genocide;

(e) Complicity in genocide." (Genocide Convention, 1951: Article III).

This criminal liability is not limited to somebody on the local level who is acting on orders from above, which are not an excuse for such a crime. Instead, everybody involved in genocide is to be held accountable under Article IV Genocide Convention:

"Persons committing genocide or any of the other acts enumerated in article III shall be punished, whether they are constitutionally responsible rulers, public officials or private 
individuals" (Genocide Convention, 1951: Article IV).

In addition to treaty law, genocide is also outlawed as a matter of customary international law. Most importantly, the prohibition of genocide is a peremptory norm of international law. These norms, also referred to as jus cogens, must be respected at all times. This concept is enshrined for example in article 53 of the Vienna Convention on the Law of Treaties (Vienna Convention on the Law of Treaties, 1969), to which the United States is a party as well. No exception to this prohibition is possible, under no circumstance, not even in times of war. Only a few norms enjoy this high status and the prohibition of genocide is right among the top norms of international law.

\subsection{U.S. Criminal Law}

While the United States has not ratified the Rome Statute and although the current administration in Washington D.C. is strongly opposed to the International Criminal Court (ICC), the United States remains a party to the Genocide Convention. As such, it has a duty to implement the Genocide Convention. One of the key duties in this regard is the obligation to fight genocide through national criminal law. Like in the case of the ICC or the international tribunals dealing with war crimes and crimes against humanity in places like Rwanda or the former Yugoslavia, international courts take the second seat when compared to national courts. This is reflective of international human rights law in general. It is first and foremost on the local level that international human rights law and international criminal law are implemented.

In the United States, genocide is defined as a crime under 18 U.S. Code $\S 1091$ :

"(a)Basic Offense.-Whoever, whether in time of peace or in time of war and with the specific intent to destroy, in whole or in substantial part, a national, ethnic, racial, or religious group as such-

(1)kills members of that group;

(2)causes serious bodily injury to members of that group; (3)causes the permanent impairment of the mental faculties of members of the group through drugs, torture, or similar techniques; (4)subjects the group to conditions of life that are intended to cause the physical destruction of the group in whole or in part;

(5)imposes measures intended to prevent births within the group; or

(6)transfers by force children of the group to another group;

shall be punished as provided in subsection (b). (b)Punishment for Basic Offense.-The punishment for an offense under subsection (a) is-

(1)in the case of an offense under subsection (a)(1), where death results, by death or imprisonment for life and a fine of not more than $\$ 1,000,000$, or both; and

(2)a fine of not more than $\$ 1,000,000$ or imprisonment for not more than twenty years, or both, in any other case.

(c)Incitement Offense.-

Whoever directly and publicly incites another to violate subsection (a) shall be fined not more than $\$ 500,000$ or imprisoned not more than five years, or both.

(d)Attempt and Conspiracy.-

Any person who attempts or conspires to commit an offense under this section shall be punished in the same manner as a person who completes the offense.

(e)Jurisdiction.-There is jurisdiction over the offenses described in subsections (a), (c), and (d) if-

(1) the offense is committed in whole or in part within the United States; or

(2) regardless of where the offense is committed, the alleged offender is-

(A) a national of the United States (as that term is defined in section 101 of the Immigration and Nationality Act (8 U.S.C. 1101));

(B)an alien lawfully admitted for permanent residence in the United States (as that term is defined in section 101 of the Immigration and Nationality Act (8 U.S.C. 1101));

(C) a stateless person whose habitual residence is in the United States; or

(D)present in the United States.

(f)Nonapplicability of Certain Limitations. Notwithstanding section 3282, in the case of an offense under this section, an indictment may be found, or information instituted, at any time without limitation" (18 U.S.C. $\$ 1091)$. 
This wording, in particular that of subsection (a) of 18 U.S.C. $\S 1091$, is clearly based on Article II of the Genocide Convention. Both preventing births in a group and the transfer of children are forms of genocide which are punishable under U.S. law with up to twenty years of imprisonment. Notably, genocide is the rare example for a crime for which, under international law, somebody who aides in the commission of the crime, is punished as not merely as an accessory but as a perpetrator (Dörr, 2018: 657).

\subsection{A Duty to Investigate}

The allegations are serious and I hope that they are not true. If they are true, justice must be done. This means that the rule of law, the impartiality and independence of the judiciary, have to be guaranteed in order to allow for a proper investigation in accordance with due process rules as required by U.S. law and international human rights standards. It is essential for everybody involved, victims as well as suspects, to have as clear a legal process as possible. America has many excellent jurists and they should be allowed to do their job without outside interference. The severity of the case allows for nothing short of a clear investigation which answers all questions and contributes to the prevention of genocide under all circumstances. Anything else would be an insult to those who build their hopes on and who have given their lives for the values that America and its constitution have long stood for. America is capable of greatness and of delivering justice. It is up to the people of America to ensure justice for all, especially for those who are detained under inhumane conditions.

\section{HISTORICAL AND CONTEMPORARY CONTEXT}

\subsection{History}

But genocide is not new to the Americas. According to history, genocide in America dates back to the time of Spanish colonization. After the arrival of Christopher Columbus in 1492, a series of events occurred that allowed the entire American continent to be transformed. Spain, France, Holland and the United Kingdom, disputed for years these lands and resources. According to the anthropologist Darszy Ribeiro, he affirms that before the European conquest there were approximately 70 million natives and a century and a half later only 3 million would remain. In addition to this, there was death, looting of resources, slavery, torture, dispossession, etc. Also, they used the kidnapping, torture, deportation and enslavement of inhabitants of the African continent.

Despite the fact that the American Indian population was cruelly subdued and destroyed by the conquerors, much of the population reduction is attributed to diseases or pests that appeared after the arrival of the Europeans.

Unless it is used by authorities to shape societies, law, like many regulatory systems, is often reactive in nature, ideally responding to the needs of the communities it is meant to serve. International law is no different in this regard. After the international criminal trials in the wake of World War II, the attention of the global community of international lawyers (cf. Schachter, 1977; Villalpando, 2013) returned to the issue of genocide in the 1990s due to the war in the former Yugoslavia and the genocide in Rwanda (Shaw, 2017: 317) - but this does not mean that there were no acts of genocide in the meantime. Often, these acts which amount to genocide are also violations of human dignity, the idea which is at the core of international human rights law (cf. Carozza, 2015: 347).

\subsection{Modern Genocides in the Americas}

Today, cases of genocide in America continue, not only in the United States, but in the rest of the continent. A few examples shall be presented here pars pro toto.

\subsubsection{Colombia}

In the Colombian case, the indigenous peoples have maintained a constant alert for genocide. A large percentage of its population has been the victim of violence and intimidation. The National Indigenous Organization of Colombia (ONIC) 
states that indigenous peoples are experiencing genocide through massacres, selective assassinations, threats, homicides, among others. During the 50 years that the armed conflict with the FARC guerrillas lasted, the indigenous people were victims of 217 thousand violent cases. For this reason, they have insistently made different calls for attention both to the national government and to international organizations so that the necessary individual and collective protection measures for their population are taken.

"In Colombia it has not yet been possible to clarify whether or not there is genocide among the most vulnerable population, mainly due to the situation of armed conflict that the country has been going through for decades, especially in the rural areas further away from the capital. However, it is important to recognize that crimes against different populations are constantly and prolonged committed by multiple actors who exercise legal or illegal power in the country. [...] Although in Colombia there have been no extermination processes on scales similar to those of genocides sanctioned in the international context, it can be seen that this complex criminal pattern of ethnic, social and political collectivities has often resulted in not only the elimination of many of its leaders and members, but their total or partial extermination. (1). For this reason, the regulations in force in the country include in the definition of the concept of genocide, unlike international treaties, the annihilation of political groups (2). In national legislation, then, it is part of genocide to try to destroy or destroy all or part of a group for political reasons and to try to cause or cause the death of its members by reason of their belonging to it. The factual and historical reality has therefore had to be translated into a normative reality that expresses it" (Cepeda, 2020). All the activities carried out by organizations in Colombia in charge of defending human rights have been insufficient due to the systematic murder of social leaders. According to the Observatory of Conflicts, Peace and Human Rights of the Institute of Studies for Development and Peace (Indepaz), from January to September 2020, 204 social leaders have been assassinated in the country, and according to the report, the region with The most crimes of Human Rights defenders in the country is Cauca with 64 homicides this year. These organizations have denounced that there is no social peace in Colombia and that there are crimes against humanity, with direct responsibility of the State and that include acts that are part of a generalized attack against a defenseless civilian population, especially defenders of territories and of human rights.

\subsubsection{Venezuela}

Indigenous Venezuelans have also denounced on different occasions massacres perpetuated in their communities by armed men who apparently belong to the military regime of President Nicolas Maduro. Likewise, there are complaints about the dispossession carried out by the Venezuelan government to an indigenous population that ancestrally inhabited Canaima Park, which has been declared by UNESCO as a Natural Heritage of Humanity since 1994. Said territory has been a space of strong territorial disputes over the gold and diamond deposits found there and which are now being exploited by the Venezuelan government. In 2019, this situation resulted in large displacements of indigenous Venezuelans to the border with Brazil.

The genocide situation in Venezuela has spread not only to the indigenous population but also to the rest of the highly vulnerable population such as the elderly and children. Most of the families with minors have emigrated from the country looking for a better future for their children, so the child population has decreased. Meanwhile, the elderly population remains in Venezuela, without any possibility of improving their quality of life; Medical care for this group of the population is being denied; Hospitals in Venezuela are closing due to lack of supplies and medical personnel. This situation would be accelerating their natural process towards death.

Therefore, the reality of North America is not very far from the rest of the American continent. 
Genocide continues to be a threat of annihilation for different social groups for different reasons, both racial and political.

\subsubsection{Argentina}

Rafael Vasquez Rivera, filed a lawsuit before the courts of Argentina against the United States government genocide by omission after his mother and aunt died of COVID-19 in the State of California. It affirms that "the measures were not taken in a timely manner, and at a chronological level it can be shown how the entire North American people and consequently the international community were left in a situation of dispossession, causing any of the compatriots to contract the disease, as happened with me, my mother and my aunt, who were fatal victims" (Sebastian, 2020).

\subsubsection{Brazil}

In the same way, in Brazil, complaints were filed on July 26, 2020 against President Jair Baolsonaro before the International Criminal Court for managing the Covid 19 pandemic. They were filed by more than one million workers of the health of Brazil, refer to genocide and crimes against humanity. Also, four more complaints were filed at the Netherlands-based ICC related to the handling of the coronavirus crisis and acts that lead to the genocide of indigenous communities.

One of the main commitments that a president assumes is to protect his population by making the best decisions with efficiency and responsibility, but apparently, the Bolsonaro government made decisions insensibly and managed the pandemic in a negligent way, especially by refusing to protect the Brazilian health workers and the community in general.

\section{CONCLUDING REMARKS}

This whole situation reflects that genocide in America is more present than ever. In the United States, Latinos have had to endure a different mode of genocide towards their population. The number of Latinos in North America exceeds 59 million, of which almost 36 million are of Mexican origin between the legal and illegal population.
In the same way, a strong campaign of hatred towards immigrants has increased.

To carry out the anti-immigrant policies advanced by President Donald Trump, detention centers for migrants, similar to concentration camps, have been built. There are approximately 200 of these immigration detention centers in the United States, where around 50,000 illegal immigrants, refugees and asylum seekers from Latin America remain, 24 of which have died due to being in overcrowded conditions.

There is a greater concern for the children who are in these places, because the conditions are not suitable for them to remain minors. Some of these minors have lost their lives in charge of the Immigrant Reception Centers of the United States, due to the inhumane conditions of confinement in which thousands of people find themselves. They are concentration centers where human rights apparently do not exist.

Given the above situation, it is possible to say that the Trump administration and the democracy of the United States and the rest of America are going through one of their worst moments, which could propose some modifications that allow updating and confronting the traditional democratic model Faced with a problematic joint that gives him the appearance of weakness. This could be a way of seeking a democratic balance and deepening its institutional framework. That is why crises force systems to rethink to overcome them.

"Democracy has been attacked by increasingly recurrent expressions of fundamentalist violence and groups that spread terror throughout the planet. The counterpart of said violence is manifested in a state of permanent fear of citizens and human rights violations as part of a state of security or emergency implemented by the governments of many countries, configuring a panorama of restriction of civil rights and political and the application of proven physical and symbolic violence among the members of 
numerous minorities and communities that inhabit those territories" (De La Cuadra \& Paredes, 2017:7).

A rule of law would be a State that defends human rights and that accesses citizen participation in decision-making and not simply a normative concept to validate a system of social control. The main right to defend would be the right to life, which should not be denied absolutely to anyone regardless of their social condition, race, religion or political affiliation.

Democracy must be inclusive and allow broad participation and debate regarding the use of state power as an instrument of social control in order to guarantee justice in an inclusive manner to protect the human rights of people and legitimize the systems.
Therefore, there remains a great effort to improve the capacity for social justice and equality, reformulating the political power of the current State from citizen participation, leaving aside the absolute power of the State, which has lost wide recognition as a result of the dissatisfaction of society and the lack of guarantees that allow a timely response to their demands.

International law plays an important role in the improvement of the protection of human rights. In particular, in the words of Méndez and Cone, "Latin American communities have adopted the language of international human rights, perhaps more so than in other regions of the world, to advance the construction of more just and free societies with accountable governments" (Méndez \& Cone, 2015: 955).

\section{BIGLIOGRAFÍA}

- Associated Press (2020). "China cuts Uighur births with IUDs, abortion, sterilization", Associated Press, 29 June 2020, https:// apnews.com/269b3de1af34e17c1941a514 f78d764c.

- Associated Press (2018). “Deported parents may lose kids to adoption, investigation finds", NBC News, 9 October 2018, https:// www.nbcnews.com/news/latino / deported-parents-may-lose-kids-adoptioninvestigation-finds-n918261.

- BBC (2019). "Data leak reveals how China 'brainwashes' Uighurs in prison camps", $B B C$ News, 24 November 2019, https://www.bbc. com/news/world-asia-china-50511063.

- BBC (2020). "ICE whistleblower: Mexico investigating US immigrant 'sterilisations'", in: BBC News, 23 September 2020, h t t p s : / / www.b b c.com / new s / world-latin-america-54265571.

- Carozza, Paolo G. (2015). "Human Dignity", in: Shelton, Dinah (ed.), The Oxford Handbook of International Human Rights
Law, Oxford: Oxford University Press, pp. 345-359.

- Cepeda, Iván (2020). "Sobre el Crimen de Genocidio en Colombia" Telesur, 19 septiembre 2020, https://www.telesurtv. net/opinion/Sobre-el-crimen-degenocidio-en-Colombia-20200811-0025. html.

- Convention on the Prevention and Punishment of the Crime of Genocide (Genocide Convention), adopted 9 December 1948, entered into force 12 January 1951, 78 United Nations Treaty Series 277, https://treaties.un.org/doc/ Treaties/1951/01/19510112\%200812\%20PM/Ch_IV_1p.pdf.

- Cryer, Robert (2018). "International Criminal Law", in: Evans, Malcom D. (ed.), International Law. Oxford: Oxford University Press, pp. 743-773.

- De La Cuadra, Fernando y Paredes Juan Pablo (2017). "Las Amenazas y Desafíos de la Democracia", Santiago de Chile, POLIS, 
Revista Latinoamericana, vol. 16, núm. 46, 2017, pp. 5 - 16.

- Dörr, Oliver (2018). "7. Kapitel: Völkerrechtliche Verantwortlichkeit", in: Ipsen, Knut. Völkerrecht. Munich: C.H. Beck, pp. 625-691.

- Goldman, Francisco (2012). "Children of the Dirty War", The New Yorker, 12 March 2012, https://www.newyorker. c o m / m a g a zin e / $2012 / 03 / 19$ / children-of-the-dirty-war.

- Guardian staff and agencies (2020). "Family separations at US border plagued by problems, watchdog finds", The Guardian, 6 March 2020, https://www.theguardian. com/us-news/2020/mar/06/trumpborder-separations-children-mexicowatchdog.

- Lambe, Jerry (2020). “'Like an Experimental Concentration Camp': Whistleblower Complaint Alleges Mass Hysterectomies at ICE Detention Center", Law \& Crime, 14 September 2020, https://lawandcrime. com/high-profile/like-an-experimentalconcentration-camp-whistleblowercomplaint-alleges-mass-hysterectomies-atice-detention-center/.

- Long, Clara (2019). "Written Testimony: "Kids in Cages: Inhumane Treatment at the Border"', Human Rights Watch, 11 June 2019, https://www.hrw.org/news/2019/07/11/ written-testimony-kids-cages-inhumanetreatment-border.

- López-Terra, Federico (2018). "The 'stolen babies' trial in Spain finally shines a light on a scandal that cannot be forgotten", The Conversation, 13 July 2018, https:// theconversation.com/the-stolen-babiestrial-in-spain-finally-shines-a-light-on-ascandal-that-cannot-be-forgotten-99860.

- Méndez, Juan E. \& Cone, Catherine (2015). "Human Rights Make A Difference: Lessons from Latin America", in: Shelton, Dinah (ed.), The Oxford Handbook of International Human Rights Law, Oxford: Oxford
University Press, pp. 955-979.

- Rome Statute of the International Criminal Court, adopted 17 July 1998, entered into force 1 July 2002, 2187 United Nations Treaty Series 3, https://treaties.un.org/ doc/Treaties/1998/07/19980717\%200633\%20PM/Ch_XVIII_10p.pdf.

- Schachter, Oscar (1977). "The invisible college of international lawyers". Northwestern University Law Review 12, pp. 217-226.

- Sebastian, D. (2020). “Denuncian genocidio al omitir medidas contra el Covid", https:// www.ambito.com/informacion-general/ trump/denuncian-argentina-eeuu-ygenocidio-al-omitir-medidas-contra-elcovid-19-n5127378.

- Shaw, Malcom N. (2017). International Law. Cambridge: Cambridge University Press.

- U.S. Code, 18 U.S. Code $\S 1091$. Genocide, https://www.law.cornell.edu/uscode/ text/18/1091.

- Vienna Convention on the Law of Treaties, adopted 23 May 1969, entered into force 27 January 1980, 1155 United Nations Treaty Series 331, https://treaties.un.org/ doc/Treaties/1980/01/19800127\%200052\%20AM/Ch_XXIII_01.pdf.

- Villalpando, Santiago (2013). "The "Invisible College of International Lawyers" Forty Years Later", European Society of International Law Conference Paper Series, Conference Paper No. 5/2013, Amsterdam Research Forum, 23-25 May 2013, http:// dx.doi.org/10.2139/ssrn.2363640.

- Washington Post Editorial board (2020). "How China corralled 1 million people into concentration camps", Washington Post, 29 February 2020, https://www.washingtonpost. com/opinions /global-opinions/aspreadsheet-of-those-in-hell-how-chinacorralled-uighurs-into-concentrationcamps/2020/02/28/4daeca4a-58c8-11eaab68-101ecfec2532_story.html. 